Original Research Paper

\title{
Ethnobotanical Study of Medicinal Plants Used to Treat Degenerative Disease in East Lombok
}

\author{
Dyke Gita Wirasisya ${ }^{*}$, Nisa Isneni Hanifa ${ }^{1}$, Wahida Hajrin ${ }^{1}$ \\ ${ }^{1}$ Program Studi Farmasi, Fakultas Kedokteran, Universitas Mataram, Mataram, Indonesia
}

\author{
Article History \\ Received : October $18^{\text {th }}, 2020$ \\ Revised : November $12^{\text {th }}, 2020$ \\ Accepted : November $15^{\text {th }}, 2020$ \\ Published : November $17^{\text {th }}, 2020$ \\ *Corresponding Author: \\ Dyke Gita Wirasisya, \\ Program Studi Farmasi, Fakultas \\ Kedokteran, Universitas \\ Mataram, Mataram, Indonesia; \\ Email: dykegita_w@unram.ac.id
}

\begin{abstract}
Degenerative diseases have become a complex problem around the world. Until now, degenerative diseases have become the biggest cause of death in the world. Approximately, 17 million people die early each year due to the global epidemic of degenerative diseases. Peoples in developing countries still rely on medicinal plants for primary health care. The knowledge for medicinal plant were passed down through generation with little written documentation. This study aimed to document the indigenous medicinal plants used for the treatment for degenerative diseases in East Lombok, Indonesia and to find leads on prospective plants for further ethnopharmacology research based on quantitative ethnobotany index. The ethnomedicinal data were collected through interview and discussion among local healers and plant collected with the help of local guide also herbarium was made to aid specimen confirmation. Ethnomedicinal data was analyzed using use value (UV) along with fidelity level (FL). A total of 20 informants (traditional healers) were interviewed and from the study we can documented the use of 63 plants for the treatment of degenerative diseases. The UV ranged from 0,05 (Sesbania grandiflora) to 0,35 (Carica papaya), while the highest FL (100\%) was found for 29 species. Based on the ethnobotanical index (UV and FL) from each plant we can recommend 15 species for further ethnopharmacological study to determine their therapeutic effects and mechanism of action. This study revealed rich ethnomedicinal knowledge from the community in East Lombok for the treatment of degenerative disease.
\end{abstract}

Keywords: Ethnobotany; medicinal plants; degenerative disease; East Lombok

\section{Pendahuluan}

Penyakit degeneratif secara umum dapat diartikan sebagai penyakit yang terjadi karena penurunan fungsi organ tubuh dan umumnya terjadi pada usia tua (Suyono, 2006). Faktor risiko utama penyebab penurunan fungsi organ adalah pola hidup dan makan yang kurang sehat seperti banyak mengkonsumsi makanan cepat saji, kurangnya aktivitas fisik, merokok, dan meningkatnya stress (Dhani \& Yamasari, 2014). Teridentifikasi sekitar 50 jenis penyakit degeneratif yang ada saat ini, beberapa diantaranya adalah kanker, diabetes melitus, stroke, jantung koroner, obesitas dan hiperkolesterol (Nadesul, 2006; Yatim, 2006). Saat ini, terapi yang digunakan dalam penanganan penyakit degeneratif adalah dengan merubah pola hidup dan makan serta penggunaan obat. Terapi dengan obat dilakukan menggunakan sediaan obat konvensional ataupun tradisional dengan menggunakan tumbuhan obat (Destiani \& Suwantika, 2015).
Tumbuhan obat sejak zaman dahulu memainkan peranan penting dalam menjaga kesehatan dan hingga saat ini pun $48 \%$ masyarakat Indonesia masih menggunakan tumbuhan obat untuk ramuan (Kemenkes, 2018). Pemanfaatan tanaman sebagai obat pada suatu etnis terkadang hanya diketahui dan dilakukan oleh seorang dukun atau penyehat tradisional (hattra) berdasarkan metode pewarisan lisan. Pewarisan informasi dengan menggunakan metode ini mempunyai risiko tinggi untuk terlupakan sehingga penting untuk dilakukan dokumentasi dan inventarisasi mengenai tumbuhan obat yang digunakan (Diantaris, Susanti \& Anggraito, 2015) terutama untuk penyakit degeneratif. Penelitian etnomedisin saat ini tidak hanya dilakukan untuk keperluan inventarisasi data tumbuhan obat, namun juga digunakan untuk mencari tanaman potensial guna penulusuran lanjut terkait senyawa baru dengan aksi farmakologis (Silalahi, 2016).

Kajian yang dilakukan bertujuan untuk melakukan 
eksplorasi terkait data etnomedisin di kecamatan Masbagik, Pringgasela, Sakra dan Wanasaba, Lombok Timur. Kabupaten Lombok Timur merupakan kabupaten terluas di pulau Lombok, namun hanya ditemukan beberapa kajian terkait etnomedisin pada daerah ini (Atwazah, Sukenti \& Wirasisya, 2019; Rahayu, Rustiami \& Rugayah, 2016). Data etnomedisin yang berhasil terdokumentasi kedepannya diharapkan dapat dipergunakan sebagai landasan untuk pengujian lanjutan dan bahan masukan dalam pelayanan kesehatan tradisional.

\section{Bahan dan Metode}

Penelitian yang dilakukan adalah survei eksploratif. Desain penelitian didukung dengan pendekatan dan teknik pengumpulan partisipatif (partisipatory ethnobotany appraisal) meliputi wawancara semi terstruktur dan terjadwal untuk mengetahui pengetahuan lokal serta mengambil sampel guna pemastian spesies (Martin, 1995).

\section{Waktu dan tempat}

Penelitian dilakukan di Kabupaten Lombok Timur pada kecatamatan Masbagik, Pringgasela, Sakra dan Wanasaba. Pengambilan data dilaksanakan pada bulan April - November 2019.

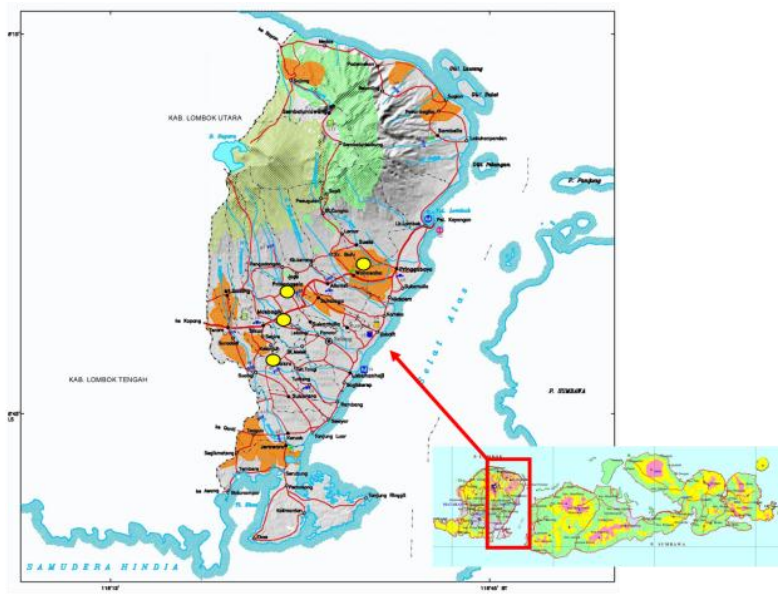

Gambar 1. Lokasi penelitian

\section{Wawancara dan dokumentasi}

Wawancara yang digunakan dalam penelitian ini secara keseluruhan menggunakan teknik semi terstruktur. Kriteria informan yang dipergunakan antara lain:

1. Memiliki pengetahuan mengenai penggunaan bahan obat/tumbuhan dan ramuan dalam pengobatan.

2. Penduduk asli atau yang telah mengalami enkulturasi.

3. Dikenal oleh masyarakat sebagai orang yang memiliki pengetahuan tentang bahan/tumbuhan dan ramuan obat.
4. Informan yang bukan penduduk asli atau enkulturasi dan hanya memiliki pengetahuan selain tumbuhan obat tidak diikutkan dalam penelitian.

Data setiap spesies tumbuhan yang digunakan dari hasil wawancara adalah biodata informan, spesies tumbuhan obat yang digunakan, nama lokal, kegunaan, bagian yang digunakan, cara pengolahan serta cara meramunya. Data lainnya adalah bentuk ramuan tumbuhan obat dan cara pemakaiannya (Kemenkes, 2019).

\section{Pengambilan sampel dan pembuatan herbarium}

Herbarium merupakan salah satu cara mengawetkan bagian (baik daun, bunga, ranting, kuncup, buah atau bagian lainnya) dari satu spesies tumbuhan. Adapun tahapan pembuatan herbarium adalah sebagai berikut:

1. Pengambilan contoh bagian tumbuhan obat (batang, daun, bunga, biji atau buah).

2. Beri label gantung pada tumbuhan obat. Label gantung berisi nomor koleksi, inisial nama kolektor, tanggal pengambilan spesimen, nama lokal spesimen dan lokasi pengambilan spesimen.

3. Sampel dibersihkan dan disiram dengan alkohol $70 \%$ hingga seluruh bagian tersiram merata.

4. Sampel dirapikan dan dimasukkan ke dalam lipatan kertas koran.

5. Setelah sampai di tempat koleksi herbarium, tumpukan herbarium dipres dalam sasak, kemudian dimasukkan ke dalam oven dengan suhu $70^{\circ} \mathrm{C}$ selama 3 hari.

6. Setelah kering, herbarium kemudian dimounting pada kertas (Kemenkes, 2019).

\section{Pengolahan dan analisis data}

Analisis data dilakukan secara deskriptif dan kuantitatif. Analisis deskriptif dilakukan terhadap data karakteristik informan, ramuan dan bahan obat yang didapatkan dari informan. Analisis kuantitatif dilakukan pada tanaman obat dengan menentukan beberapa indeks etnobotani (Hoffman \& Gallaher, 2007), antara lain Use Value (UV) dan Fidelity Level (FL).

Use Value (UV)

$$
U V_{i s}=\left(\Sigma U_{i s}\right) /\left(n_{i s}\right)
$$

$\mathbf{U}_{\text {is }}=$ jumlah penggunaan tanaman

$\mathbf{n}_{\text {is }}=$ jumlah event

Fidelity Level (FL)

$$
F L=\frac{I_{p}}{I_{u}} * 100 \%
$$

Ip = jumlah informan yang menggunakan tanaman spesifik untuk keperluan tertentu.

$\mathbf{I u}=$ total informan yang menggunakan tanaman spesifik. 


\section{Hasil dan Pembahasan}

\section{Lokasi Penelitian dan Data Demografi Informan}

Lokasi pengamatan dilakukan pada Kabupaten Lombok Timur di 4 kecamatan yaitu Masbagik, Pringgasela, Sakra dan Wanasaba. Lokasi tersebut dipilih berdasarkan keberadaan penyehat tradisional (hattra).

Hasil pencarian pada penelitian ini didapatkan 26 hattra dimana hanya 20 orang yang memenuhi kriteria. Profil dari hattra yang diwawancara adalah $75 \%$ (15 orang) berjenis kelamin laki-laki dan $25 \%$ (5 orang) berjenis kelamin perempuan dengan persebaran umur $10 \%$ berumur 20 - 40 tahun dan $90 \%$ berumur di atas 40 tahun. Sebagian besar hattra mendapatkan pengetahuannya secara turun-temurun $(75 \%)$, namun ada pula yang mendapatkan pengetahuan dari pengalaman serta dari alam gaib dan mimpi (25\%). Hattra sebagian besar memiliki pendidikan tertinggi SD (Sekolah Dasar), bahkan ada yang tidak pernah bersekolah sama sekali, dan hanya sebagian kecil yang berpendidikan SMA (Sekolah Menengah Atas) ataupun PT (Perguruan Tinggi).

Dari hasil penelitian dapat dilihat bahwa hattra dengan umur diatas 40 tahun berjumlah lebih banyak
(90\%). Kurangnya jumlah generasi muda yang tertarik terhadap pengobatan tradisional dapat disebabkan oleh sulitnya mendapatkan penghasilan yang layak jika berprofesi sebagai hattra dan juga adanya perkembangan pengobatan konvensional. Kejadian seperti ini juga ditemukan di negara Pakistan dan Turki (Adnan, dkk 2014; Cakilcioglu, dkk 2011). Metode pewarisan informasi pengobatan yang dilakukan oleh hattra diempat kecamatan, mayoritas menggunakan metode lisan. Metode pewarisan seperti ini sangat umum dijumpai (Hong, dkk 2015).

\section{Jenis Tanaman Untuk Pengobatan}

Hasil penelitian didapatkan 74 ramuan yang dimasukkan kedalam 9 kategori penyakit yaitu darah tinggi (14 ramuan), gangguan kebugaran (8 ramuan), kecing manis (21 ramuan), kolesterol tinggi (5 ramuan), panas dalam (3 ramuan), pegal/capek (2 ramuan), sakit jantung (8 ramuan), stroke/lumpuh (8 ramuan) dan kanker/tumor (5 ramuan). Tercatat sebanyak 63 jenis tanaman yang dipergunakan untuk ramuan tersebut, namun 12 diantaranya belum teridentifikasi spesiesnya. Daftar tanaman untuk tiap kategori penyakit dapat dilihat pada Tabel 1.

Tabel 1. Jenis tumbuhan obat berdasar kategori penyakit.

\begin{tabular}{|c|c|c|}
\hline Kategori Penyakit & Nama Lokal Tumbuhan & Nama Spesies \\
\hline \multirow[t]{10}{*}{ Stroke/ Lumpuh } & Buak & Areca catechu \\
\hline & Nyiur & Cocos nucifera \\
\hline & Kunyit & Curcuma longa \\
\hline & Adas & Foeniculum vulgare \\
\hline & Beras & Oriza Sativa \\
\hline & Pandan & Pandanus sp \\
\hline & Knampokan & Physalis angulata \\
\hline & Brotowali & Tinospora crispa \\
\hline & Antap & Vigna unguiculata \\
\hline & Boboran & - \\
\hline \multirow[t]{8}{*}{ Sakit Jantung } & Bawang abang & Allium сера \\
\hline & Kesune & Allium sativum \\
\hline & Gedang & Carica papaya \\
\hline & Jae bereng ate & Curcuma aeruginosa \\
\hline & Sabo & Manilkara zapota \\
\hline & Bagekan & Phyllanthus niruri \\
\hline & Kenampokan & Physalis angulata \\
\hline & Bikan & - \\
\hline \multirow[t]{4}{*}{ Panas Dalam } & Jeringo & Acorus calamus \\
\hline & Buak & Areca catechu \\
\hline & Semanggi & Marsilea $s p$ \\
\hline & Ketrian & - \\
\hline \multirow[t]{2}{*}{ Pegal/ Capek } & Imbe & Azadirachta indica \\
\hline & Gedang & Musa sp \\
\hline
\end{tabular}


Dyke Gita Wirasisya et al. (2020). Jurnal Biologi Tropis, 20 (3): 423 - 431

DOI: http://dx.doi.org/10.29303/jbt.v20i3.2119

\begin{tabular}{|c|c|c|}
\hline Kategori Penyakit & Nama Lokal Tumbuhan & Nama Spesies \\
\hline \multirow[t]{7}{*}{ Kolesterol Tinggi } & Kesune & Allium sativum \\
\hline & Laos & Alpinia galanga \\
\hline & Cahar & Euphorbia heterophylla \\
\hline & Ubi Jalar & Ipomoea batatas \\
\hline & Singgapur & Muntingia calabura \\
\hline & Puntik sabe & Musa sp \\
\hline & Lempuyang & Zingiber zerumbet \\
\hline \multirow[t]{21}{*}{ Kencing Manis } & Mita & Alstonia scholaris \\
\hline & Serikaye & Annona muricata \\
\hline & Gedang & Carica papaya \\
\hline & Nyiur & Cocos nucifera \\
\hline & Lomak & Colocasia esculenta \\
\hline & Perenggi & Cucurbita moschata \\
\hline & Kunyit & Curcuma longa \\
\hline & Sekur & Curcuma xanthorriza \\
\hline & Reket bideng & Oriza Sativa var glutinosa \\
\hline & Singgepur & Muntingia calabura \\
\hline & Puntik sabe & Musa sp \\
\hline & Knampokan & Physalis angulata \\
\hline & Lekok & Piper betle \\
\hline & Jepun & Plumeria \\
\hline & Ketujur & Sesbania grandiflora \\
\hline & Mahoni & Swetenia mahogany \\
\hline & Bagek & Tamarindus indica \\
\hline & Jae abang & Zingiber officinale var rubrum \\
\hline & Sengkaor & - \\
\hline & Lengkarang & - \\
\hline & Tontongguri & - \\
\hline \multirow[t]{7}{*}{ Kanker/ Tumor } & Serikaye & Annona muricata \\
\hline & Buak & Areca catechu \\
\hline & Manggis & Garcinia mangostana \\
\hline & $\operatorname{Re}$ & Imperata cylindrica \\
\hline & Lekok & Piper betle \\
\hline & Apuh & - \\
\hline & Bunut & - \\
\hline \multirow[t]{15}{*}{ Gangguan Kebugaran } & Laos & Alpinia galanga \\
\hline & Buak & Areca catechu \\
\hline & Gedang & Carica papaya \\
\hline & Mesui & Cryptocarya massoia \\
\hline & Jae bereng ate & Curcuma aeruginosa \\
\hline & Kunyit & Curcuma longa \\
\hline & Sekur & Curcuma zanthorriza \\
\hline & $\operatorname{Re}$ & Imperata cylindrica \\
\hline & Jarak & Jatropha curcas \\
\hline & Lekok & Piper betle \\
\hline & Jambu batu & Psidium guajava \\
\hline & Tontongguri & - \\
\hline & Gende ruse & - \\
\hline & Bulo & - \\
\hline & Pupak maling & - \\
\hline \multirow[t]{2}{*}{ Darah Tinggi } & Jeringo & Acorus calamus \\
\hline & Lidah Buaye & Aloe vera \\
\hline
\end{tabular}


Dyke Gita Wirasisya et al. (2020). Jurnal Biologi Tropis, 20 (3): 423 - 431 DOI: http://dx.doi.org/10.29303/jbt.v20i3.2119

\begin{tabular}{|l|l|l|}
\hline \multicolumn{1}{|c|}{ Kategori Penyakit } & \multicolumn{1}{|c|}{ Nama Lokal Tumbuhan } & \multicolumn{1}{c|}{ Nama Spesies } \\
\hline \multirow{5}{*}{} & Gedang & Carica papaya \\
\cline { 2 - 3 } & Kupi & Coffea sp \\
\cline { 2 - 3 } & Timun & Cucumis sativus \\
\cline { 2 - 3 } & Buah naga & Hylocereus sp \\
\cline { 2 - 3 } & Bokah & Lagenaria siceraria \\
\cline { 2 - 3 } & Putri malu & Mimosa pudica \\
\cline { 2 - 3 } & Pandan & Persea americana \\
\cline { 2 - 3 } & Apokat & Tinospora crispa \\
\cline { 2 - 3 } & Brotowali &
\end{tabular}

\section{Indeks Etnobotani}

\section{Use Value}

Analisis kuantitatif dilakukan pada data etnomedisin dengan tujuan untuk menentukan potensiasi dan prioritas suatu spesies tumbuhan guna pengembangan penemuan obat baru (Faruque, dkk 2018). Penelitian ini menggunakan 2 indeks etnobotani untuk membantu memberikan justifikasi secara kuantitatif terhadap nilai satu spesies tanaman. Indeks etnobotani yang dipergunakan adalah UV dan FL.

UV merupakan indeks yang dapat menggambarkan tingkat nilai guna spesies untuk mengobati penyakit berdasar kategori yang telah ditetapkan (Silalahi, 2016). Nilai UV mengindikasikan bahwa tumbuhan tersebut sangat sering dipergunakan oleh masyarakat sekitar. Hasil indeks UV dari masingmasing spesies tanaman dapat dilihat pada Tabel 2 .

Tabel 2. Indeks UV tumbuhan obat.

\begin{tabular}{|l|l|l|}
\hline Nama Lokal & \multicolumn{1}{|c|}{ Nama Spesies } & UV \\
\hline Jeringo & Acorus calamus & 0,1 \\
\hline $\begin{array}{l}\text { Bawang } \\
\text { abang }\end{array}$ & Allium cepa & 0,05 \\
\hline Kesune & Allium sativum & 0,1 \\
\hline Lidah buaye & Aloe vera & 0,05 \\
\hline Laos & Alpinia galanga & 0,1 \\
\hline Mita' / pule & Alstonia scholaris & 0,05 \\
\hline Srikaye & Annona muricata & 0,2 \\
\hline Buak & Areca catechu & 0,2 \\
\hline Belimbing & Averrhoa carambola & 0,05 \\
\hline Imbe & Azadirachta indica & 0,1 \\
\hline Gedang & Carica papaya & 0,35 \\
\hline Bebele & Centela asiatica & 0,05 \\
\hline Jeruk nipis & Citrus aurantifolia & 0,05 \\
\hline Kenyamen & Cocos nucifera & 0,15 \\
\hline Kupi & Coffea sp & 0,05 \\
\hline Lomak/talas & Colocasia esculenta & 0,05 \\
\hline Mesui & Cryptocarya massoia & 0,1 \\
\hline Timun & Cucumis sativus & 0,05 \\
\hline Perenggi & Cucurbita moschata & 0,05 \\
\hline Jae bereng ate & Curcuma aeruginosa & 0,1 \\
\hline & & \\
\hline
\end{tabular}

\begin{tabular}{|c|c|c|}
\hline Nama Lokal & Nama Spesies & $\mathbf{U V}$ \\
\hline Inen kunyik & Curcuma longa & 0,15 \\
\hline Sekur & Curcuma xanthorriza & 0,2 \\
\hline Cahar & Euphorbia heterophylla & 0,05 \\
\hline Adas & Foeniculum vulgare & 0,15 \\
\hline Manggis & Garcinia mangostana & 0,05 \\
\hline Buah naga & Hylocereus sp & 0,05 \\
\hline Jujuk re & Imperata cylindrica & 0,1 \\
\hline Ubi jalar & Ipomoea batatas & 0,1 \\
\hline Jarak & Jatropha curcas & 0,05 \\
\hline Reket bideng & $\begin{array}{l}\text { Oriza Sativa var } \\
\text { glutinosa }\end{array}$ & 0,05 \\
\hline Bokah & Lagenaria siceraria & 0,1 \\
\hline Sabo & Manilkara zapota & 0,05 \\
\hline Semanggi & Marsilea $s p$ & 0,05 \\
\hline Putri malu & Mimosa pudica & 0,1 \\
\hline Singgapur & Muntingia calabura & 0,15 \\
\hline Pisang & Musa sp & 0,1 \\
\hline Beras beak & Oriza Sativa & 0,1 \\
\hline Pandan & Pandanus sp & 0,1 \\
\hline Alpukat & Persea americana & 0,15 \\
\hline Bagekan & Phyllanthus niruri & 0,05 \\
\hline Knamplosam & Physalis angulata & 0,15 \\
\hline Leko & Piper betle & 0,2 \\
\hline Jepun putih & Plumeria & 0,1 \\
\hline Jambu batu & Psidium guajava & 0,05 \\
\hline Ketujur & Sesbania grandiflora & 0,05 \\
\hline Mahoni & Swetenia mahogany & 0,05 \\
\hline Bagek & Tamarindus indica & 0,1 \\
\hline Brotowali & Tinospora crispa & 0,1 \\
\hline Antap & Vigna unguiculata & 0,15 \\
\hline Jae abang & $\begin{array}{l}\text { Zingiber officinale var } \\
\text { rubrum }\end{array}$ & 0,05 \\
\hline Lembuyang & Zingiber zerumbet & 0,05 \\
\hline Boboran & - & 0,1 \\
\hline Bikan & - & 0,1 \\
\hline Ketrian & - & 0,05 \\
\hline Pupak sapah & - & 0,05 \\
\hline Sengkaor & - & 0,05 \\
\hline Lengkarang & - & 0,05 \\
\hline Tontongguri & - & 0,1 \\
\hline Apuh & - & 0,05 \\
\hline
\end{tabular}


Dyke Gita Wirasisya et al. (2020). Jurnal Biologi Tropis, 20 (3): 423 - 431 DOI: http://dx.doi.org/10.29303/jbt.v20i3.2119

\begin{tabular}{|l|l|c|}
\hline Nama Lokal & \multicolumn{1}{c|}{ Nama Spesies } & UV \\
\hline Bunut & - & 0,05 \\
\hline Gende ruse & - & 0,05 \\
\hline Bulo & - & 0,05 \\
\hline Pupak maling & - & 0,05 \\
\hline
\end{tabular}

Carica papaya sebagai tumbuhan dengan nilai UV paling tinggi pada penelitian ini merupakan tumbuhan yang sering dipergunakan dalam kebutuhan sehari-hari (sayur-mayur dan buah). Klaim hattra mengatakan bahwa tumbuhan ini dapat mengobati penyakit darah tinggi, gangguan kebugaran, kencing manis, pegal/capek dan jantung.

\section{Fidelity level}

Indeks selanjutnya adalah FL yang merupakan indeks yang dapat menghitung tingkat kepentingan suatu spesies pada penyakit tertentu (Hoffman \& Gallaher, 2007) dimana semakin besar nilai FL pada satu spesies mengindikasikan bahwa spesies itu sangat dipercaya untuk digunakan sebagai obat pada suatu kategori penyakit. Pada Tabel 3 terlihat adanya spesies dengan tingkat kepentingan tinggi $(\mathrm{FL}=100)$. Hal ini dimungkinkan terjadi karena adanya satu spesies dengan penggunaan tunggal dan hanya sekali disebutkan oleh hattra ataupun karena adanya satu spesies dengan penggunaan tunggal namun disebutkan berulang oleh hattra.

Tabel 3. Indeks FL tumbuhan obat.

\begin{tabular}{|c|c|c|c|}
\hline Kategori Penyakit & Nama Lokal & Nama Spesies & FL \\
\hline \multirow[t]{10}{*}{ Stroke/ Lumpuh } & Buak & Areca catechu & 50 \\
\hline & Kenyamen & Cocos nucifera & 66,67 \\
\hline & Inen kunyik & Curcuma longa & 33,33 \\
\hline & Sekur & Curcuma zanthorriza & 50 \\
\hline & Adas & Foeniculum vulgare & 66,67 \\
\hline & Putri malu & Mimosa pudica & 50 \\
\hline & Beras beak & Oriza Sativa & 100 \\
\hline & Pandan & Pandanus sp & 50 \\
\hline & Knamplosam & Physalis angulata & 33,33 \\
\hline & Brotowali & Tinospora crispa & 50 \\
\hline \multirow[t]{8}{*}{ Sakit Jantung } & Bawang abang & Allium сера & 100 \\
\hline & Kesune & Allium sativum & 50 \\
\hline & Gedang & Carica papaya & 14,29 \\
\hline & Jae bereng ate & Curcuma aeruginosa & 50 \\
\hline & Sabo & Manilkara zapota & 100 \\
\hline & Bagekan & Phyllanthus niruri & 100 \\
\hline & Knamplosam & Physalis angulata & 33,33 \\
\hline & Bikan & - & 100 \\
\hline \multirow[t]{4}{*}{ Panas Dalam } & Langko/ jeringo & Acorus calamus & 50 \\
\hline & Buak & Areca catechu & 25 \\
\hline & Semanggi & Marsilea $s p$ & 100 \\
\hline & Ketrian & - & 100 \\
\hline \multirow[t]{2}{*}{ Pegal/Capek } & Imbe & Azadirachta indica & 50 \\
\hline & Pisang & Musa sp & 50 \\
\hline \multirow[t]{7}{*}{ Kolesterol Tinggi } & Langko/ jeringo & Acorus calamus & 50 \\
\hline & Kesune & Allium sativum & 50 \\
\hline & Laos & Alpinia galanga & 50 \\
\hline & Cahar & Euphorbia heterophylla & 100 \\
\hline & Ubi jalar & Ipomoea batatas & 50 \\
\hline & Singgapur & Muntingia calabura & 33,33 \\
\hline & Pisang & Musa sp & 50 \\
\hline \multirow[t]{4}{*}{ Kencing Manis } & Mita' / pule & Alstonia scholaris & 100 \\
\hline & Srikaye & Annona muricata & 50 \\
\hline & Imbe & Azadirachta indica & 50 \\
\hline & Gedang & Carica papaya & 42,86 \\
\hline
\end{tabular}


Dyke Gita Wirasisya et al. (2020). Jurnal Biologi Tropis, 20 (3): 423 - 431

DOI: http://dx.doi.org/10.29303/jbt.v20i3.2119

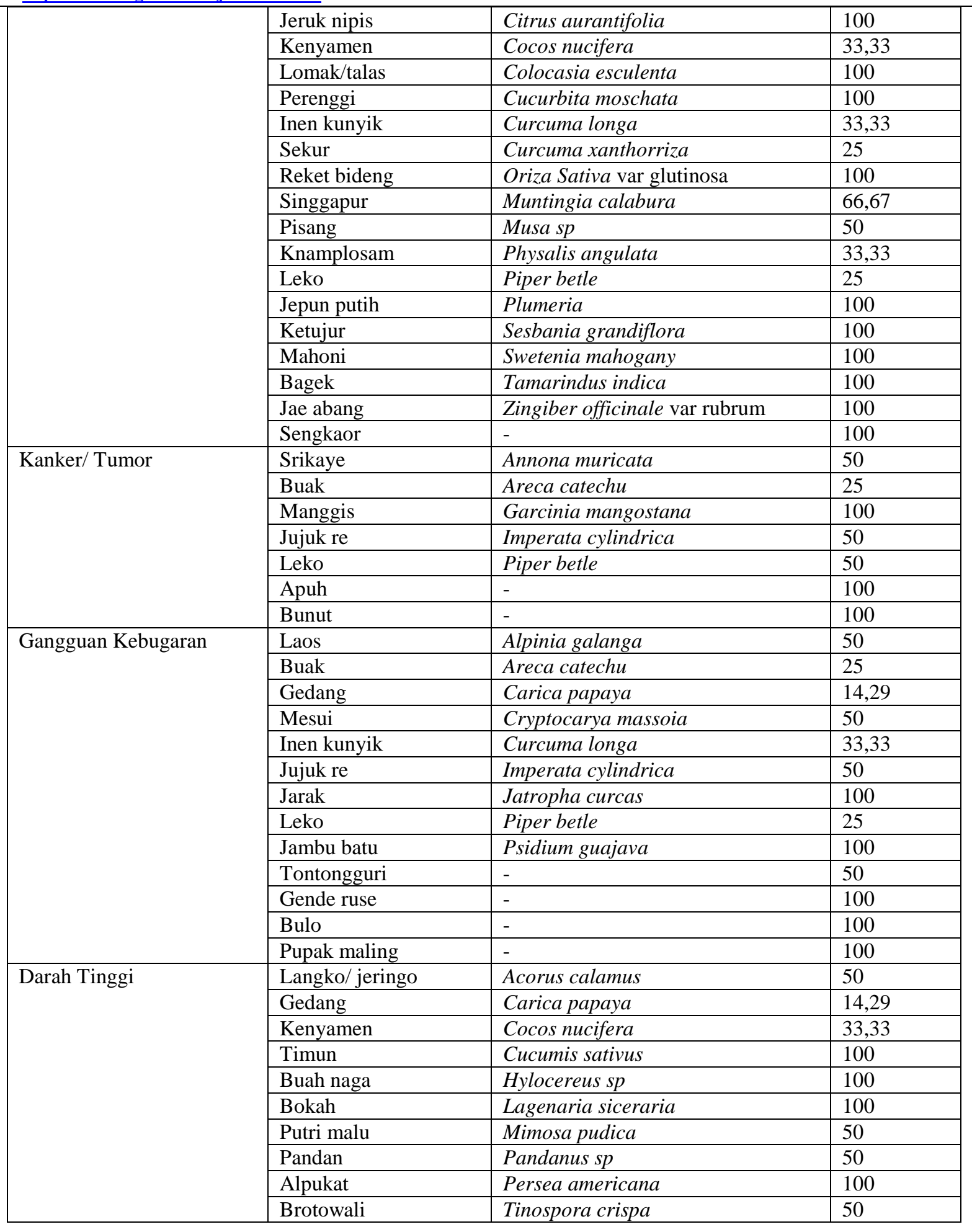

Kasus penggunaan tanaman pada kategori darah tinggi terdeteksi spesies terpenting (FL hingga 100\%) adalah Cucumis sativus, Lagenaria siceraria, Hylocereus $s p$ dan Persea americana, namun dari keempat spesies tersebut yang disebutkan lebih dari satu kali oleh beberapa hattra hanya Persea americana. Data dari kasus diatas dapat menyebabkan misleading sehingga kesimpulan yang dihasilkan pada nantinya juga harus mempertimbangkan nilai UV pada tiap spesies atau dapat melakukan koreksi pada nilai FL dengan memberikan 
koreksi menggunakan nilai RPL (Relative Popularity Level) (Hoffman \& Gallaher, 2007; Umair, Muhammad \& Arshad, 2019).

Berikut adalah tanaman obat prioritas dengan mempertimbangkan nilai UV dan FL untuk setiap kategori penyakit: darah tinggi (Carica papaya, Persea americana), gangguan kebugaran (Areca catechu, Carica papaya, Curcuma longa, Piper betle), kecing manis (Annona muricata, Carica papaya, Curcuma longa, Curcuma xanthorriza, Muntingia calabura, Physalis angulate, Piper betle), kolesterol tinggi (Acorus calamus, Allium sativum, Alpinia galanga, Euphorbia heterophylla, Muntingia calabura), panas dalam (Areca catechu), pegal/capek (Azadirachta indica), sakit jantung (Carica papaya, Physalis angulata), stroke/lumpuh (Areca catechu, Curcuma xanthorriza, Foeniculum vulgare, Physalis angulate, Curcuma longa) dan kanker/tumor (Annona muricata, Areca catechu, Piper betle). Beberapa foto spesies tanaman dapat dilihat pada gambar 2.

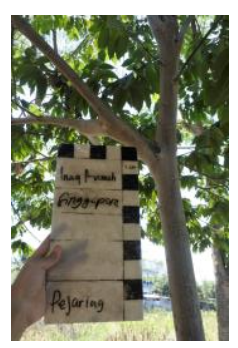

A

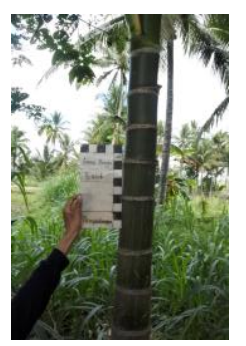

B

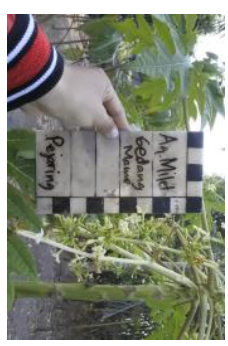

C
Gambar 2. Muntingia calabura (A), Areca catechu (B) dan (C) Carica papaya.

\section{Kesimpulan}

Jumlah ramuan yang berhasil didokumentasi dari penelitian yang telah dilakukan adalah 74 ramuan dengan 63 jenis tumbuhan obat yang berhasil identifikasi, dan 12 tumbuhan belum dapat teridentifikasi. Inventarisasi kearifan lokal terkait ramuan tradisonal perlu dilakukan untuk menghindari hilangnya pengetahuan tersebut mengingat bahwa hattra tidak menuliskan pengetahuan tersebut.

\section{Ucapan terima kasih}

Terimakasih kepada Fakultas Kedokteran, Universitas Mataram yang telah memberikan pendanaan penelitian dari dana Dipa PNBP.

\section{Referensi}

Adnan, M., Ullah, I., Tariq, A., Murad, W., Azizullah, A. \& Khan, A.L. (2014). Ethnomedicine use in the war affected region of northwest Pakistan. $J$

Ethnobiol Ethnomed, 10:1-16.

https://doi.org/10.1186/1746-4269-10-16

Atwazah, T.I., Sukenti, K. \& Wirasisya, D.G (2019). Antimicrobial Potential of Methanol Extract from Kastuba Leaf (Euphorbia pulcherrima Willd.). Natural-B, 5:13-18.

Cakilcioglu, U., Khatun, S., Turkoglu, I. \& Hayta, S. (2011). Ethnopharmacological survey of medicinal plants in Maden (Elazig-Turkey). $J$ Ethnopharmacol, https://doi.org/10.1016/j.jep.2011.05.046

Destiani, D.P. \& Suwantika, A.A. (2015). Penggunaan Suplemen Herbal sebagai Upaya Swamedikasi di Kota Bandung. Jurnal Farmasi Klinik Indonesia, 4:71-76.

Dhani, S.R. \& Yamasari, Y. (2014). Rancang Bangun Sistem Pakar untuk Mendiagnosa Penyakit Degeneratif. Jurnal Manajemen Informatika, 3:17-25.

Diantaris, M.T.A., Susanti, R. \& Anggraito, Y.U. (2015). Diversity and Utilization of Medicinal Plants by Sasak Ethnic at Central Lombok District, West Nusa Tenggara. International Conference on Mathematics, Science, and Education 2015, 19-22.

Faruque, M.O., Shaikh, B.U., James, W.B., Sheng, Hu, Shuang, Dong., Qian, Cai., Xiaohua, Li. \& Xuebo, Hu. (2018). Quantitative ethnobotany of medicinal plants used by indigenous communities in the Bandarban District of Bangladesh. Frontiers in pharmacology, 9:1-12. https://doi.org/10.3389/fphar.2018.00040

Hoffman, Bruce. \& Gallaher, T. (2007). Importance Indices in Ethnobotany. Ethnobotany Research and Application, 5:201-218.

Hong, L., Guo, Z., Huang, K., Wei, S., Liu, B. \&Meng, S. (2015). Ethnobotanical study on medicinal plants used by Maonan people in China. J Ethnobiol Ethnomed, 11:1-34. https://doi.org/10.1186/s13002-015-0019-1

Kementerian Kesehatan Republik Indonesia. (2018). Riset Kesehatan Dasar (Riskesdas) 2018. Badan Penelitian dan Pengembangan Kesehatan Kementerian Kesehatan Republik Indonesia. Jakarta. 
Kementerian Kesehatan Republik Indonesia. (2017). Eksplorasi Pengetahuan Lokal Etnomedisin Dan Tumbuhan Obat Berbasis Komunitas Di Indonesia: Provinsi Nusa Tenggara Barat, Badan Penelitian dan Pengembangan Kesehatan Kementerian Kesehatan Republik Indonesia. Jakarta.

Martin, G. J. (1995). Ethnobotany A Methods Manual. Springer. Boston.

Nadesul, Handrawan. (2006). Sehat Itu Murah. PT. Kompas Media Nusantara, Jakarta.

Rahayu, M., Rustiami, H. \& Rugayah. (2016). Ethnobotanical Study of Sasak Ethnic, East Lombok, West Nusa Tenggara. Journal of Tropical Biology and Conservation, 13:85-99.
Silalahi, Marina. (2016). Studi Etnomedisin di Indonesia dan Pendekatan Penelitiannya. JDP, 9:117-124.

Suyono, S. (2006). Buku ajar Ilmu Penyakit Dalam. Pusat penerbitan Ilmu Penyakit dalam Fakultas Kedokteran Universitas Indonesia, Jakarta.

Umair, M., Muhammad, A. \& Arshad, M.A. (2019). An ethnobotanical survey of indigenous medicinal plants in Hafizabad district, Punjab-Pakistan. PloS one, 12:1-22. https://doi.org/10.1371/journal.pone.0177912

Yatim, Faisal. (2006). Penyakit Tulang dan Persendian. Penerbit PT Populer Obor, Jakarta. 